\title{
Accepting Educational Responsibility for an Inclusive University Campus: The Impact of the Diversity Ambassador Program
}

\author{
Susan R. Warren \\ Azusa Pacific University \\ Richard S. Martinez \\ Azusa Pacific University \\ Maria A. Pacino \\ Azusa Pacific University
}

\begin{abstract}
This investigation explored the benefits of a 4-year voluntary diversity professional development program for over 200 faculty and staff in an urban, private university. The research team engaged institutional stakeholders to examine, reflect, and expand a platform for research, practice, and policy centered on issues of diversity. The researchers investigated ways in which the diversity program impacted the institutional climate. Mixed-methods combined quantitative measurements of staff and faculty perspectives on growth through diversity professional development and qualitative analysis of perceptions of the programmatic impact. Findings indicate significantly increased commitment as a community to advocacy, personal and professional development, and creating a university-wide inclusive campus climate. This information will assist educators seeking more inclusive campuses through diversity professional development initiatives.
\end{abstract}

Keywords: faculty and staff professional development program, cultural proficiency program, higher education, inclusive college campus, diversity training program

\section{PURPOSE}

The purpose of this study is to assess the impact of a voluntary diversity professional development program for faculty and staff at an institution of higher education serving over 11,000 highly diverse students in an urban setting. A pilot of the Diversity Ambassador Program began in 2014 with 13 participants. Since then, over 200 faculty and staff have participated in the program. Diversity training will only impact organizational ethos to the extent to which participants transfer and apply knowledge to work contexts (Goldstein, Behm-Morawitz, \& Hays, 2018). This study assesses the growth of faculty and staff in understanding the value of diversity at both the individual and organizational levels as well as participants' desire and confidence in taking action for the purpose of inclusion. 


\section{PERSPECTIVES}

\section{Educational Context}

The United States is increasingly diverse. It is projected that by 2050 non-Hispanic whites will become a minority (Population Reference Bureau, 2014). This trend is also reflected in college student demographics (Kingkade, 2015; Mason, 2014), yet faculty and staff remain predominantly white and middle-class (Smith, 2009). Additionally, campus climates often reflect white norms that prevent students of color from feeling a sense of belonging or thriving (Ash \& Schreiner, 2016). It is an ethical imperative that faculty and staff develop a level of cultural competence, sensitivity, and a commitment to supporting diverse populations, creating more inclusive environments and preparing all students to participate in a global society (Burnell \& Schnackenberg, 2015; Goldstein, Behm-Morawitz, \& Hays, 2018).

The Diversity Ambassador Program (DAP) was designed to provide personal and professional growth around issues of diversity for university employees and encourage them to become leaders as they support colleagues in their journey toward cultural competence. It is based on a theoretical approach to increasing cultural competence (Lindsey, Nuri Robins, Terrell, \& Lindsey, 2019) and cognitive coaching skills (Linsdey, Martinez, Lindsey, \& Myatt, 2019). The first pilot group of ambassadors worked with the Office of Diversity, sponsors of the program, to refine the program mission and develop face to face and online diversity resources for professional development (PD). The purpose of the DAP is to foster a multidimensional, transformative commitment to diversity in staff, faculty, and administrators as they work to ensure all students and other members of the university community feel respected, are successful, and thrive in their university experience. Over a four-year period, individuals voluntarily registered for the program and approximately 30 diversity ambassadors were in each cohort participating in six 3-hour sessions of professional development fall or spring. Aside from the traditional cohorts, three areas within the university chose to participate in special DAP cohorts in which all members of the department attended and with content somewhat customized for their field of work. Additionally, all ambassadors were invited to continue their diversity PD through lunchtime special speakers (often diversity ambassadors) who presented enriching topics for discussion. This was in addition to monthly optional diversity workshops available for all employees. After four years of program implementation, the researchers collaborated with the now Center for Diversity, Equity, and Inclusive Excellence and a group of ambassador leaders to collectively assess the impact of the DAP.

As institutions of higher education engage in evidenced-based practice and increased monitoring of learning outcomes, they also need to assess the effects of the diversity initiatives that enhance campus diversity climate. While there is ample research assessing the effectiveness of diversity courses for students (Cole, Case, Rios, \& Curtin, 2011), there are limited findings on the impact of diversity educational programs on staff, faculty, and administrators (Goldstein, Behm-Morawitz, \& Hays, 2018). The benefit of this study is to inform institutions of higher education of the importance of ongoing critical self-assessments on diversity initiatives and the effectiveness of this DAP (Warren, Pacino, Foy \& Bond, 2011).

Research Question: What is the impact of a voluntary diversity professional development program for faculty and staff at an urban, private university?

\section{METHODS AND DATA SOURCES}

This investigation used a mixed-methods approach including both qualitative and quantitative analysis of the perceptions of diversity ambassadors on the impact of the DAP on its participants. Data were collected from a program impact survey and nine focus groups (Creswell \& Creswell, 2018).

\section{Quantitative}

Diversity Ambassador Program Impact Survey

All 177 DAP participants ( $71 \%$ females and $29 \%$ males) still employed by the university were invited to complete the Impact Survey. Seventy-four (49\%) completed the survey. Participants self-identified as: 
male (21), female (51), not identified (2); staff/non-faculty (51), faculty (23); $49 \%$ of the staff and $18 \%$ of the faculty participants identified as persons-of-color.

The DAP impact survey was developed through a collaborative process that included the researchers and an advisory group of DA stakeholders. After reviewing the program goals and intended outcomes, the team identified six themes for assessing program impact:

1. Diversity Ambassador Growth

2. Personal/Professional Diversity Development for Colleagues

3. Mentoring or Coaching Colleagues

4. Strategic Diversity Action Planning

5. Diversity Resource Development and Dissemination

6. Advocating for Diversity, Equity, and Inclusive Excellence

Twenty-nine questions were designed to assess program impact within these themes. The diversity ambassador advisory group piloted the survey and provided feedback; the team made appropriate adjustments to the questions. Demographic categories were included in the survey for the purpose of analyzing differences in impact between groups; these categories included primary position, gender, and race/ethnicity. Of the 29 items, 27 were measured by Likert scales and two by multiple choice options. Additionally, a composite mean score was generated for each impact theme by grouping individual item scores.

Analysis of the impact survey findings began with descriptive statistics identifying the highest scoring items within each theme. A series of independent samples t-tests and Chi-Square tests for independence were utilized comparing findings by demographic groups. Statistically significant differences between groups in program impact were identified.

\section{Qualitative}

\section{Focus Groups}

A random selection process for focus group participation was implemented by a university intern external to the research process. DAs from the 7 cohorts 2014-2018 were randomly invited to attend a semistructured focus group with others from the same cohort. Seeking up to six participants per cohort group, the selection process continued until as many slots were filled as possible. Due to some DAs' scheduling issues, two additional focus groups were added for a total of nine. The same researchers and advisory group of DA stakeholders developed the guiding questions based on results of the Impact Survey. The questions were designed to have DA focus group participants share their perspectives about the program's impact through their personal journeys. Overall, 38 DAs participated in the focus groups; 27 females and 11 males. They self-identified as persons-of-color (19), white (18), other (1); staff/non-faculty (29), faculty (10); and they represented a wide-range of years at the institution and departments. All focus groups were transcribed verbatim for analysis.

\section{Open-Ended Items From the Impact Survey}

Four questions on the Impact Survey were open-ended and the responses were analyzed as a distinct qualitative data source. The prompts asked participants to elaborate on their most significant contribution to the university as a result of the DAP, how the program impacted their workplace, and any additional feedback about the impact.

Analysis of the qualitative data utilized a constant-comparison method (Creswell \& Creswell, 2018). A team of four researchers collaborated in determining the initial coded categories and by consensus they reconfirmed, re-named, or re-grouped the categories as needed to determine the impact of the DAP, if any, perceived by the ambassadors through their participation in the program. They identified open-ended patterns and axial themes. Finally, the researchers reflected on: What best characterizes the more global nature of the DAs' perceptions of the program's impact on the university? Triangulation was accomplished by comparing the separate sources of data (Huberman, Miles \& Saldana, 2013). 


\section{RESULTS}

\section{Quantitative}

Tables 1 through 9 include the overall mean score results for each impact survey item grouped by theme. A separate table was used for each prompt and Likert scale. Table 1 includes 18 items that utilized a 4-point frequency scale and were prompted by, "As a result of participating in the DAP...". Mean scores in each of the nine tables were sorted from highest to lowest, locating the item having the highest impact at the top of each table. Findings suggested the highest program impact was that DAs more frequently:

1. Explored their own attitudes, assumptions, and beliefs about diversity, equity, and social justice (Table 1). Theme - DA Growth;

2. Encouraged their colleagues to explore their own attitudes, assumptions, and beliefs about diversity (Table 8). Theme - Personal and Professional Development:

3. Furthered their own personal and professional development in the area of diversity through collaborating with others (Table 3). Theme - DA Growth.

4. Provided diversity-related professional development for people within their own department, through one-on-one conversations and small groups (Tables 4, 5, and 6). Theme - Personal and Professional Development:

Findings from the impact survey themes and items were compared between specific demographic groupings of the sample population: faculty versus staff, female versus male, and employees of color versus White. For six out of the seven statistically significant findings, faculty impact scores were higher than staff scores $(\mathrm{p} .<.05)$. Another significant finding was that the impact score for female employees was higher than for males $(\mathrm{p} .<.05)$.

Tables 10 and 11 reflect statistically significant findings. Faculty scored significantly higher than nonfaculty in three impact themes: Advocating for Diversity, Mentoring or Coaching, Personal/Professional Growth, and females scored significantly higher than males on one Diversity Ambassador Growth item regarding connecting with experts $(\mathrm{p} .<.05)$. A Chi-Square test for Independence revealed that faculty were significantly more likely than staff to have provided diversity-related PD for their colleagues through large group presentations, as a result of participating in the DAP, $\mathrm{X} 2(1, \mathrm{~N}=74)=4.58, \mathrm{p}<.05$.

\section{Qualitative}

Several patterns emerged throughout the qualitative data. Table 13 displays open patterns and axial themes. These were analyzed and three global themes emerged characterizing the impact of the DAP: increased commitment as a community to advocacy, personal and professional development, and creating a university-wide inclusive campus climate (Table 14).

\section{Overall Findings}

The quantitative data support the qualitative findings in that the four items indicating the highest program impact (Tables 1-9) from the Impact Survey are aligned with the Global Themes that emerged from the two qualitative data sources. Finding 3 regarding DAs more frequently furthering their own personal and professional development in the area of diversity through collaborating with others supports the global theme of a community committed to advocacy focused on diversity, equity, and social justice as a result of the DAP. Finding 1 regarding DAs more frequently exploring their own attitudes, assumptions, and beliefs about diversity, equity, and social justice and finding 4 about DAs providing diversity-related professional development within their own department, through one-on-one conversations and small groups, support the global theme of an increased commitment to personal and professional development in diversity for self and colleagues. Finding 2, regarding DAs more frequently encouraging colleagues to explore their own attitudes, assumptions, and beliefs about diversity supports the global theme of a commitment to creating an inclusive campus climate university-wide as a result of the DAP. The overall impact of this program was positive in that faculty, staff, and institutional leaders reported significant benefits from participating as DAs. These benefits will be addressed in detail in the final AERA paper. 


\section{SCHOLARLY SIGNIFICANCE}

This investigation will inform educators across three levels. The study provides valuable information for: (a) professional developers in higher education who work with staff and faculty in nurturing organizational support for diversity, (b) higher education departments and school leaders in developing inclusive organizational cultural practices, and (c) researcher and stakeholder collaboratives in promoting cross-organizational relationships for research leading to support for diversity. The information will assist these groups as they accept educational responsibility for creating inclusive campus climates in higher education by structuring and implementing impactful diversity PD programs.

\section{REFERENCES}

Ash, A.N., \& Schreiner, L.A. (2016). Pathways to success for students of color in Christian colleges: The role of institutional integrity and sense of community. Christian Higher Education, 15(1-2), 3861.

Burnell, B., \& Schnackenberg, H. (2015). The ethics of cultural competence in higher education. Palm Bay, FL: Apple Academic Press.

Colby, S.L., \& Ortman, J.M. (2014). Projections of the size and composition of the U.S. population: 2014 to 2060. Current Population Reports, P25-1143, U.S. Census Bureau, Washington, DC.

Cole, E.R., Case, K.A., Rios, D., \& Curtin, N. (2011). Understanding what students bring to the classroom: Moderators of the effects of diversity courses on student attitudes. Cultural Diversity and Ethnic Minority Psychology, 17(4), 397-405. https://doi.org/10.1037/a0025433

Creswell, J.W., \& Creswell, J.D. (2018). Research design: Qualitative, quantitative, and mixed methods approaches (5th ed.). SAGE.

Goldstein Hode, M., Behm-Morawitz, E., \& Hays, A. (2018). Testing the effectiveness of an online diversity course for faculty and staff. Journal of Diversity in Higher Education, 11(3), 347-365.

Kingkade, T. (2015). Decade of change for college students: Less religious, more diverse and lonely. HuffPost. Retrieved from https://www.huffpost.com/entry/college-10-years-changes_n_7201460

Lindsey, D.B., Martinez, R.S., Lindsey, R.B., \& Myatt, K.T. (2019). Culturally proficient coaching: Supporting educators to create equitable schools (2nd ed.). Corwin Press.

Lindsey, R.B., Nuri Robins, K., Terrell, R.D., \& Lindsey, D.B. (2019). Cultural proficiency: A manual for school leaders (4th ed.). Corwin Press, Inc.

Mason, K.C. (2014, August). As student bodies get more diverse, colleges rethink services. PBS News Hour. Retrieved from https://www.pbs.org/newshour/education/one-size-wont-fit-rethinkingcampuses-growing-diversity

Smith, D.G. (2009). Diversity's Promise for Higher Education. The Johns Hopkins University Press.

Warren, S.R., Pacino, M.A., Foy, T., \& Bond, T. (2011). An NCATE Approved school of education selfstudy on diversity: Faculty and student perceptions. Educational Considerations, 38(2), 36-42. 


\section{APPENDIX}

\section{Overall Scores by Prompt Sorted Highest to Lowest}

\section{TABLE 1 \\ OVERALL MEAN SCORE RESULTS: AS A RESULT OF PARTICIPATING IN THE DIVERSITY AMBASSADOR TRAINING PROGRAM (4-POINT FREQUENCY SCALE)}

\begin{tabular}{|c|c|c|c|}
\hline Theme & Survey item & $\mathbf{M}$ & SD \\
\hline $\begin{array}{l}\text { Diversity } \\
\text { Ambassador }\end{array}$ & $\begin{array}{l}\text { I explore my own attitudes, assumptions, and beliefs about diversity, } \\
\text { equity, and social justice. }\end{array}$ & 3.68 & 0.598 \\
\hline \multirow[t]{3}{*}{ Growth } & I have progressed in my cultural competence. & 3.60 & 0.744 \\
\hline & I am challenged to grow in my cultural competence. & 3.56 & 0.764 \\
\hline & $\begin{array}{l}\text { I use cognitive coaching skills in my conversations with others about } \\
\text { diversity. }\end{array}$ & 2.99 & 0.950 \\
\hline \multirow[t]{2}{*}{$\begin{array}{l}\text { Strategic Action } \\
\text { Planning }\end{array}$} & $\begin{array}{l}\text { I work with college, school, department leaders and/or fellow } \\
\text { diversity ambassadors to develop strategic diversity plans for creating } \\
\text { a more inclusive environment, including professional development } \\
\text { around issues of diversity. }\end{array}$ & 2.78 & 1.024 \\
\hline & $\begin{array}{l}\text { I engage with others in revising policies, practices, programs, or } \\
\text { services to ensure that they equitably meet the needs of marginalized } \\
\text { groups within APU. }\end{array}$ & 2.47 & 1.113 \\
\hline \multirow[t]{3}{*}{ Resources } & $\begin{array}{l}\text { I share reading and other materials with my colleagues to aid in } \\
\text { identifying and recognizing systems or structures with persistent } \\
\text { inequities }\end{array}$ & 2.46 & 0.939 \\
\hline & $\begin{array}{l}\text { I promote or develop diversity-related materials and projects that } \\
\text { integrate issues of diversity, equity, and/or social justice (e.g., } \\
\text { curriculum development, workshop presentations, cross-disciplinary } \\
\text { projects, and research). }\end{array}$ & 2.40 & 1.127 \\
\hline & $\begin{array}{l}\text { I collaborate with colleagues to increase/enhance resources to support } \\
\text { diverse members of the APU community (e.g. facilitating community } \\
\text { engagement, collaborating with experts, partnering with other } \\
\text { university areas, and incorporating service learning) }\end{array}$ & 2.37 & 0.979 \\
\hline \multirow[t]{3}{*}{$\begin{array}{l}\text { Mentoring or } \\
\text { coaching }\end{array}$} & $\begin{array}{l}\text { I mentor/coach individual staff of diverse cultural backgrounds in } \\
\text { various areas (e.g., skill development, career } \\
\text { enhancement/advancement). }\end{array}$ & 2.03 & 1.040 \\
\hline & $\begin{array}{l}\text { I mentor/coach individual faculty of diverse cultural backgrounds in } \\
\text { various areas (e.g. teaching, research, scholarship, career } \\
\text { enhancement/advancement). }\end{array}$ & 1.58 & 0.965 \\
\hline & $\begin{array}{l}\text { I mentor/coach individual administrators of diverse cultural } \\
\text { backgrounds in various areas (e.g., teaching, research, career } \\
\text { enhancement/advancement, leadership skills). }\end{array}$ & 1.51 & 0.940 \\
\hline
\end{tabular}


TABLE 2

OVERALL MEAN SCORE RESULTS: AS A RESULT OF PARTICIPATING IN THE DIVERSITY AMBASSADOR TRAINING (4-POINT QUALITY SCALE)

\begin{tabular}{|c|c|c|c|}
\hline Theme & Survey item & $\mathbf{M}$ & SD \\
\hline \multirow{5}{*}{$\begin{array}{l}\text { Advocating for diversity, } \\
\text { equity, and inclusive } \\
\text { excellence at APU }\end{array}$} & $\begin{array}{l}\text { I believe that Diversity Ambassadors are welcome in my } \\
\text { college, school, or department. }\end{array}$ & 3.46 & 0.797 \\
\hline & $\begin{array}{l}\text { I advocate for hiring practices and processes that consistently } \\
\text { identify diverse, culturally competent candidates. }\end{array}$ & 2.73 & 1.064 \\
\hline & $\begin{array}{l}\text { I advocate for diversity, equity, and inclusive excellence at } \\
\text { APU by serving on university committees or groups }\end{array}$ & 2.69 & 1.097 \\
\hline & $\begin{array}{l}\text { I develop diversity-related projects (e.g., curriculum } \\
\text { development, workshop presentations across the } \\
\text { university/regional campuses, cross-disciplinary projects) }\end{array}$ & 2.18 & 1.064 \\
\hline & $\begin{array}{l}\text { I conduct research/publish on diversity, equity, social justice, } \\
\text { or other related topics }\end{array}$ & 1.84 & 1.205 \\
\hline
\end{tabular}

TABLE 3

OVERALL MEAN SCORE RESULTS: I AM COMMITTED TO FURTHERING MY PERSONAL AND PROFESSIONAL DEVELOPMENT IN THE AREA OF DIVERSITY THROUGH: (4-POINT QUALITY SCALE)

\begin{tabular}{llcc}
\hline Theme & Survey item & M & SD \\
\hline Diversity Ambassador & Collaborating with others & 3.44 & 0.645 \\
Growth & Exploring new resources (e.g. books, videos) & 3.16 & 0.817 \\
& Attending diversity workshops & 3.08 & 0.84 \\
& Connecting with experts (e.g. mentor, coach, other & 3.01 & 0.874 \\
& & \\
\hline
\end{tabular}

TABLE 4

OVERALL RESULTS: I HAVE PROVIDED DIVERSITY-RELATED PROFESSIONAL DEVELOPMENT FOR MY COLLEAGUES THROUGH: (CHECK ALL THAT APPLY)

\begin{tabular}{llcc}
\hline Theme & Survey item & $\mathbf{\%}$ & $\mathbf{N}$ \\
\hline Personal/ Professional Development & One-to-one conversations, & $83 \%$ & 62 \\
& Small group discussions, & $56 \%$ & 42 \\
& Staff or faculty meeting activities, & $55 \%$ & 41 \\
& Small group presentations, & $35 \%$ & 26 \\
& Large group presentations & $27 \%$ & 20 \\
\hline
\end{tabular}


TABLE 5

OVERALL RESULTS: I PREFER THE FOLLOWING AUDIENCE SIZE WHEN PROVIDING DIVERSITY-RELATED PROFESSIONAL DEVELOPMENT: (CHECK ALL THAT APPLY)

\begin{tabular}{llcc}
\hline Theme & Survey item & $\mathbf{\%}$ & $\mathbf{N}$ \\
\hline Personal/ Professional Development & Small group (2-12) & $79 \%$ & 59 \\
& Individual (one-to-one) & $68 \%$ & 51 \\
& Large group (over 12) & $31 \%$ & 23 \\
\hline
\end{tabular}

TABLE 6

OVERALL RESULTS: I PROVIDE DIVERSITY-RELATED PROFESSIONAL DEVELOPMENT FOR: (CHECK ALL THAT APPLY)

\begin{tabular}{llcc}
\hline Theme & Survey item & \% & N \\
\hline $\begin{array}{l}\text { Personal/Professional } \\
\text { Development }\end{array}$ & My college, school, or department & $69 \%$ & 52 \\
& $\begin{array}{l}\text { External individuals/groups (e.g., family, friends, church, } \\
\text { community or other organizations) }\end{array}$ & $45 \%$ & 34 \\
& Colleagues at APU outside of my area & $35 \%$ & 26 \\
\hline
\end{tabular}

TABLE 7

OVERALL MEAN SCORE RESULTS: I WORK WITH FELLOW DIVERSITY

AMBASSADORS IN MY AREA TO PLAN AND IMPLEMENT DIVERSITY

ACTIVITIES THROUGH: (5-POINT FREQUENCY SCALE)

\begin{tabular}{llcc}
\hline Theme & Survey item & M & SD \\
\hline \multirow{2}{*}{ Strategic Action Planning } & Formal meetings & 3.13 & 1.510 \\
& Informal meetings (e.g. conversations with a colleague) & 2.92 & 1.148 \\
\hline
\end{tabular}


TABLE 8

OVERALL MEAN SCORE RESULTS: SINGLE ITEMS (NO PROMPT)

(4-POINT FREQUENCY SCALE)

\begin{tabular}{llcc} 
Theme & Survey item & M & SD \\
\hline $\begin{array}{l}\text { Personal/ } \\
\begin{array}{l}\text { Professional } \\
\text { Development }\end{array}\end{array}$ & $\begin{array}{l}\text { I encourage my colleagues to explore their own attitudes, } \\
\text { assumptions, and beliefs about diversity. }\end{array}$ & 3.19 & 0.783 \\
& $\begin{array}{l}\text { I assist my colleagues in recognizing how their personal background } \\
\text { (e.g. class, gender, religion, race, and ethnicity) and experiences } \\
\text { impact their beliefs and behaviors toward others. }\end{array}$ & 2.85 & 0.783 \\
& $\begin{array}{l}\text { I support new staff and faculty of diverse cultural backgrounds in } \\
\text { navigating cultural spaces within the university system. }\end{array}$ & 2.8 & 0.944 \\
& $\begin{array}{l}\text { I assist with groups or activities to foster broader discourse on issues } \\
\text { of diversity, equity, and/or social justice (e.g. a workshop on } \\
\text { microaggressions or a diversity reading group). }\end{array}$ & 2.64 & 0.981 \\
& $\begin{array}{l}\text { I facilitate activities to develop cultural proficiency in my } \\
\text { colleagues. }\end{array}$ & 2.40 & 1.010 \\
\hline
\end{tabular}

TABLE 9

OVERALL MEAN SCORE RESULTS: SINGLE ITEMS (NO PROMPT) (4-POINT AGREEMENT SCALE)

\begin{tabular}{llcc} 
Theme & Survey item & M & SD \\
\hline $\begin{array}{l}\text { Diversity } \\
\text { Ambassador Growth }\end{array}$ & I believe the Diversity Ambassador program has positively & 3.14 & 0.956 \\
\hline
\end{tabular}

Statistically Significant Findings

TABLE 10

STATISTICALLY SIGNIFICANT RESULTS OF INDEPENDENT-SAMPLES T-TESTS

COMPARING FACULTY TO STAFF FOR DIVERSITY AMBASSADOR'S PROGRAM IMPACT SURVEY THEMES

\begin{tabular}{|c|c|c|c|c|c|c|c|}
\hline \multirow[b]{2}{*}{ Impact Theme } & \multirow[b]{2}{*}{$d f$} & \multicolumn{2}{|c|}{ Faculty } & \multicolumn{2}{|c|}{$\begin{array}{l}\text { Staff (non- } \\
\text { faculty) }\end{array}$} & \multirow[b]{2}{*}{$\boldsymbol{I}$} & \multirow[b]{2}{*}{ Cohen's a } \\
\hline & & $M$ & $S D$ & $M$ & $S D$ & & \\
\hline $\begin{array}{l}\text { Advocating for diversity, equity, and } \\
\text { inclusive excellence }\end{array}$ & 35 & 52.68 & 7.717 & 48.79 & 6.230 & $2.122 *$ & 0.55 \\
\hline Mentoring or coaching & 72 & 53.03 & 9.685 & 48.63 & 7.682 & $2.095 *$ & 0.50 \\
\hline
\end{tabular}

*p $<.05,{ }^{* *} \mathrm{p}<.01$

Cohen's d Effect Size scale: 0.2 Small, 0.5 Medium, 0.8 Large 
TABLE 11

STATISTICALLY SIGNIFICANT RESULTS OF INDEPENDNET=SAMPLE T-TESTS COMPARING FACULTY TO STAFF AND FEMALES TO MALES FOR DIVERSITY AMBASSADOR'S PROGRAM IMPACT SURVEY ITEMS ORGANIZED BY IMPACT THEME - AS A RESULT OF PARTICIPATING IN THE DIVERSITY AMBASSADOR TRAINING PROGRAM

\begin{tabular}{|c|c|c|c|c|c|c|c|c|}
\hline \multirow{2}{*}{$\begin{array}{l}\text { Impact } \\
\text { Theme }\end{array}$} & \multirow[b]{2}{*}{ Items } & \multirow[b]{2}{*}{$d f$} & \multicolumn{2}{|c|}{ Faculty } & \multicolumn{2}{|c|}{$\begin{array}{l}\text { Staff (non- } \\
\text { faculty) }\end{array}$} & \multirow[b]{2}{*}{$t$} & \multirow{2}{*}{$\begin{array}{c}\text { Cohen's } \\
d\end{array}$} \\
\hline & & & $M$ & $S D$ & $M$ & $S D$ & & \\
\hline \multirow{2}{*}{$\begin{array}{l}\text { Advocating } \\
\text { for diversity, } \\
\text { equity, and } \\
\text { inclusive } \\
\text { excellence }\end{array}$} & $\begin{array}{l}\text { I develop diversity-related } \\
\text { projects }\end{array}$ & 72 & 2.61 & 1.158 & 1.98 & 0.969 & $2.427 *$ & 0.59 \\
\hline & $\begin{array}{l}\text { I conduct research/publish } \\
\text { on diversity, equity, social } \\
\text { justice, or other related } \\
\text { topics }\end{array}$ & 30 & 2.57 & 1.472 & 1.51 & 0.903 & $3.180 * *$ & 0.87 \\
\hline \multirow[t]{2}{*}{$\begin{array}{l}\text { Mentoring or } \\
\text { coaching }\end{array}$} & $\begin{array}{l}\text { I mentor/coach: Individual } \\
\text { faculty of diverse cultural } \\
\text { backgrounds in various } \\
\text { areas (e.g. teaching, } \\
\text { research, scholarship, career } \\
\text { enhancement/advancement). }\end{array}$ & 31 & 2.13 & 1.140 & 1.33 & 0.766 & $3.056^{* *}$ & 0.82 \\
\hline & & & \multicolumn{2}{|c|}{ Female } & \multicolumn{2}{|c|}{ Male } & & \\
\hline $\begin{array}{l}\text { Diversity } \\
\text { Ambassador } \\
\text { Growth }\end{array}$ & $\begin{array}{l}\text { Connecting with experts } \\
\text { (e.g. mentor, coach, other } \\
\text { colleague) }\end{array}$ & 69 & 3.16 & 0.834 & 2.65 & 0.933 & $2.228^{*}$ & 0.58 \\
\hline
\end{tabular}




\section{TABLE 12 \\ STATISTICALLY SIGNIFICANT RESULTS OF INDEPENDENT-SAMPLE T TESTS FOR SPRING 2019 DIVERSITY AMBASSADOR TRAINING BY PRE AND POST SURVEYS}

\begin{tabular}{|c|c|c|c|c|c|c|c|c|}
\hline \multirow[b]{2}{*}{ Survey Section } & \multirow[b]{2}{*}{ Survey Item } & \multirow[b]{2}{*}{$d f$} & \multicolumn{2}{|c|}{ Pre } & \multicolumn{2}{|c|}{ Post } & \multirow[b]{2}{*}{$t$} & \multirow{2}{*}{$\begin{array}{l}\text { Effect- } \\
\text { Size r }\end{array}$} \\
\hline & & & $M$ & $S D$ & $M$ & $S D$ & & \\
\hline \multirow[t]{2}{*}{$\begin{array}{l}\text { Section 1: } \\
\text { Knowledge } \\
\text { about Cultural } \\
\text { Proficiency }\end{array}$} & $\begin{array}{l}\text { I can identify institutional } \\
\text { policies and practices that } \\
\text { address inequities and biases } \\
\text { but are short term. }\end{array}$ & 37 & 2.55 & 0.826 & 3.26 & 0.562 & $3.137^{*}$ & 0.449 \\
\hline & $\begin{array}{l}\text { I can identify institutional } \\
\text { policies and practices that } \\
\text { are based on shared values } \\
\text { and goals for equity and } \\
\text { social justice for the long } \\
\text { term. }\end{array}$ & 37 & 2.65 & 0.745 & 3.26 & 0.653 & $2.72 *$ & 0.399 \\
\hline $\begin{array}{l}\text { Section 2: Using } \\
\text { a Cultural } \\
\text { Proficiency Lens } \\
\text { to Notice and }\end{array}$ & $\begin{array}{l}\text { I am aware of what triggers } \\
\text { negative feelings in me } \\
\text { when it comes to diversity } \\
\text { (e.g. race, class, gender). }\end{array}$ & 37 & 3.20 & 0.410 & 3.53 & 0.513 & $2.199^{*}$ & 0.334 \\
\hline $\begin{array}{l}\text { Respond to } \\
\text { Interpersonal } \\
\text { Dynamics }\end{array}$ & $\begin{array}{l}\text { I try to respond to } \\
\text { microaggressions that occur } \\
\text { in my presence, including } \\
\text { coded terms and phrases. }\end{array}$ & 37 & 2.65 & 0.489 & 3.11 & 0.658 & $2.461^{*}$ & 0.368 \\
\hline \multirow{3}{*}{$\begin{array}{l}\text { Section 3: } \\
\text { Engage in } \\
\text { Actions that } \\
\text { Promote a } \\
\text { Culturally } \\
\text { Proficient } \\
\text { Campus }\end{array}$} & $\begin{array}{l}\text { I make an effort to support } \\
\text { new staff and faculty of } \\
\text { diverse cultural backgrounds } \\
\text { in navigating spaces within } \\
\text { the university. }\end{array}$ & 37 & 2.95 & 0.686 & 3.37 & 0.496 & $2.173^{*}$ & 0.331 \\
\hline & $\begin{array}{l}\text { I engage with others in } \\
\text { revising policies, practices, } \\
\text { programs, or services to } \\
\text { ensure they equitably meet } \\
\text { the needs of marginalized } \\
\text { groups within APU. }\end{array}$ & 37 & 2.60 & 0.503 & 3.05 & 0.780 & $2.166^{*}$ & 0.324 \\
\hline & $\begin{array}{l}\text { I intervene to shift cultural } \\
\text { norms and dynamics of } \\
\text { privilege to help create a } \\
\text { more equitable environment. }\end{array}$ & 37 & 2.75 & 0.444 & 3.21 & 0.535 & 2.930 & 0.423 \\
\hline
\end{tabular}

$* p<.05$

Effect Size $r$ Scale: 0.1 Small, 0.3 Medium, 0.5 Large 
TABLE 13

OPEN (*) PATTERNS AND AXIAL (>) THEMES CODED IN TWO-DATA SOURCES

\begin{tabular}{|c|c|}
\hline Impact Survey Open Ended Items & Focus Groups \\
\hline $\begin{array}{l}\text { > Increased Sense of Community } \\
\text { * Collaborated with colleagues across } \\
\text { campus } \\
\text { * Enabled challenging conversations } \\
\text { * Promoted open and honest diversity } \\
\text { communication } \\
\text { * Listened to personal narratives } \\
\text { * Developed common diversity goals }\end{array}$ & $\begin{array}{l}\text { >Increased Sense of Community } \\
\text { *Engaged in conversations in safe spaces } \\
\text { *Built relationships among faculty and staff } \\
\text { * Networked with colleagues } \\
\text { *Listened to other's voices, sharing stories and } \\
\text { experiences } \\
\text { *Developed a sense of belonging }\end{array}$ \\
\hline $\begin{array}{l}\text { >Enhanced Personal Development } \\
\text { * Increased willingness to engage } \\
\text { * Provided a supportive environment } \\
\text { * Become more open to multiple points } \\
\text { of view } \\
\text { * Explored one's attitudes and beliefs } \\
* \text { Connected social justice to faith }\end{array}$ & $\begin{array}{l}\text { Pnhanced Personal Development } \\
\text { *Increased commitment to diversity and social justice } \\
\text { *Acquired the language of diversity } \\
\text { *Challenged one's own privilege, values, and beliefs } \\
\text { *Supported colleagues in their journey } \\
\text { *Created a mindset for multiple perspectives }\end{array}$ \\
\hline $\begin{array}{l}\text { >Expanded Professional development } \\
\text { * Increased willingness to engage } \\
\text { * Become an intentional and strategic } \\
\text { advocate for social justice on campus } \\
\text { *Identify and respond to cultural biases } \\
\text { * Led diversity workshops on campus } \\
\text { * Advocated for the requirement of diversity } \\
\text { development for all employees }\end{array}$ & $\begin{array}{l}\text { Pxpanded Professional Development } \\
\text { *Was motivated agency to act } \\
\text { *Acquired communication skills } \\
\text { *Acquired Tools for diversity action planning } \\
\text { *Acquired knowledge skills and dispositions } \\
\text { *Customized content to individual departments }\end{array}$ \\
\hline $\begin{array}{l}\text { >Created Awareness of Campus Climate } \\
\text { * Identified inequities across campus } \\
\text { * Challenged implicit institutional biases } \\
\text { * Intentionally called out institutional } \\
\text { microaggressions } \\
* \text { Advocated for diversity action plans within } \\
\text { one's department } \\
* \text { Stressed the importance of diversity hiring in } \\
\text { upper administration and Board of Trustees }\end{array}$ & $\begin{array}{l}\text { >Created Awareness of Campus Climate } \\
\text { *Identified cultural barriers, particularly regarding } \\
\text { sexual orientation } \\
\text { *Advocated for more inclusive hiring practices } \\
\text { *Intentionally supported diverse students } \\
\text { *Joined a critical mass of diversity advocates } \\
\text { *Participated in diversity strategic planning }\end{array}$ \\
\hline $\begin{array}{l}\text { >Program Content and Resource } \\
\text { *Used the cultural proficiency model as a lens } \\
\text { for applying diversity in the workplace } \\
\text { * Called for more support for under- } \\
\text { represented students } \\
\text { * Expand curricular topics to include the } \\
\text { LGBTQ population } \\
\text { * Advocated for hiring more diverse faculty } \\
\text { * Incorporate program materials in curriculum } \\
\text { and instruction }\end{array}$ & $\begin{array}{l}\text { >Program Content and Resources } \\
\text { * Modeled professional development praxis } \\
\text { * Based content on theory and practice of cultural } \\
\text { proficiency } \\
\text { *Identified a need for an advanced level of content } \\
\text { for Diversity Ambassadors with higher knowledge of } \\
\text { diversity } \\
\text { *Enhanced the understanding of diversity within the } \\
\text { Christian Worldview } \\
\text { *Developed content and resources (Diversity Mosaic } \\
\text { Experience - DME, Online Diversity Course, Website } \\
\text { Resources, and outreach to Regional Campuses) }\end{array}$ \\
\hline
\end{tabular}


TABLE 14

GLOBAL THEMES EMERGING FROM TWO QUALITATIVE DATA SOURCES

\begin{tabular}{|c|l|}
\hline $\begin{array}{c}\text { Emerging Global } \\
\text { Themes }\end{array}$ & \multicolumn{1}{c|}{ Descriptors of Themes } \\
$\begin{array}{c}\text { A Community } \\
\text { Committed to } \\
\begin{array}{c}\text { Advocacy Focused on } \\
\text { Diversity, Equity, and } \\
\text { Social Justice }\end{array}\end{array}$ & $\begin{array}{l}\text { Engaged in challenging conversations in safe spaces } \\
\text { Promoted open and honest communication } \\
\text { Developed common diversity goals } \\
\text { Listened to others' personal narratives } \\
\text { Networked with colleagues about diversity issues across the university } \\
\text { Increased sense of belonging to a social justice movement }\end{array}$ \\
$\begin{array}{c}\text { A Commitment to } \\
\text { Implement } \\
\text { Professional } \\
\text { Development in } \\
\text { Diversity }\end{array}$ & $\begin{array}{l}\text { Led diversity workshops and mentored colleagues } \\
\text { Became intentional and strategic advocates for social justice } \\
\text { Advocated for the requirement for diversity development for all employees } \\
\text { Identified and responded to cultural biases } \\
\text { Developed diversity professional development resources for all university } \\
\text { constituents, face-to-face and online }\end{array}$ \\
$\begin{array}{c}\text { A Commitment to } \\
\text { Creating an Inclusive } \\
\text { Campus Climate } \\
\text { University-wide }\end{array}$ & $\begin{array}{l}\text { Challenged implicit institutional biases } \\
\text { Intentionally supported diverse students both face-to-face and online } \\
\text { Led and or participated in diversity strategic planning } \\
\text { Advocated for more inclusive hiring practices } \\
\text { Stressed the importance of diversity hiring practices in upper administration } \\
\text { and Board of Trustees }\end{array}$ \\
\hline
\end{tabular}

